\title{
多年冻土区铁路路基热状况对工程扰动及气候 变化的响应
}

\author{
马嵬 ${ }^{*}$, 穆彦虎, 李国玉, 吴青柏, 刘永智, 孙志忠 \\ 中国科学院寒区早区环境与工程研究所冻土工程国家重点实验室, 兰州 730000 \\ *E-mail: mawei@lzb.ac.cn
}

收稿日期: 2011-11-15; 接受日期: 2012-05-13

国家重点基础研究发展计划(编号: 2012CB026106)、国家自然科学基金创新群体(批准号: 41121061)和国家自然科学基金优秀国家重点实 验室研究项目(批准号: 41023003)资助

\begin{abstract}
摘要 基于青藏铁路沿线长期地温监测资料, 对天然场地及铁路路基下部的浅层地温、多年冻 土上限及下伏冻土地温动态变化过程进行对比分析, 研究多年冻土区铁路路基热状况对于工程 扰动及气候变化的响应过程. 监测结果表明, 路基修筑后边坡热效应显著, 由此导致路基下部多 年冻土热状况的不对称分布, 必须引起足够的重视. 块石路基修筑后, 下部多年冻土上限抬升显 著, 其中阴坡路肩下抬升幅度普遍较阳坡路肩下显著. 普通路基修筑后, 在年平均地温低于 $-0.6 \sim-0.7^{\circ} \mathrm{C}$ 的地区下部多年冻土上限有不同程度的抬升, 而在年平均地温高于 $-0.6^{\circ} \mathrm{C}$ 的地区下 部冻土上限则出现了一定程度的下降, 其中阳坡路肩下降幅显著. 受块石层冷却降温作用, 低温 冻土区块石路基下部浅层冻土地温有明显降温过程，而在高温冻土区这一降温趋势只存在于阴 坡路肩下. 对于普通路基, 多年冻土上限抬升后, 浅层冻土地温存在一定的升温过程. 对于气候 变暖, 低温冻土区多年冻土的响应主要集中体现在冻土升温上, 而高温冻土区多年冻土的响应则 主要表现为冻土上限下降, 冻土厚度减小。基于上述监测结果，可将目前青藏铁路路基热状况分 为稳定型(低温冻土区块石路基)、亚稳定型(低温冻土区普通路基及高温冻土区块石路基)和不稳 定型(高温冻土区普通路基).
\end{abstract}

冻土是指温度低于 $0^{\circ} \mathrm{C}$ 且含有冰的岩土或土壤, 其中土体冻结存在时间超过 2 年的称为多年冻土 ${ }^{[1,2]}$. 冻土对温度极为敏感, 尤其是对于温度在低于冰水 相变温度 $1 \sim 2^{\circ} \mathrm{C}$ 范围内的冻土, 温度的变化会对冻土 内冰晶的胶结强度以及未动水含量产生显著的影响, 进而对其物理力学性质产生严重的影响 ${ }^{[3]}$. 因此, 对 于多年冻土区工程而言, 为保证其使用寿命及长期 服役性能, 保持下部冻土的热稳定性成为科研和工
程设计人员的首要目标 ${ }^{[4]}$.

作为高原冻土铁路，青藏铁路的修建面临着严 峻的冻土路基热稳定性问题 ${ }^{[5,6]}$. 与北美和俄罗斯的 高纬度多年冻土相比, 青藏高原冻土具有地温高、厚 度小、自身热稳定性差等特点, 因此对气候变化及工 程活动的扰动更加敏感 ${ }^{[7 ~ 11]}$. 近些年来, 在气候变化 影响下, 青藏高原冻土出现了活动层厚度增加、地温 升高、多年冻土分布南北界移动等现象, 总体呈现出

中文引用格式: 马巍, 穆彦虎, 李国玉, 等. 多年冻土区铁路路基热状况对工程扰动及气候变化的响应. 中国科学: 地球科学, 2013,43: 478-489

英文引用格式: Ma W, Mu Y H, Li G Y, et al. Responses of embankment thermal regime to engineering activities and climate change along the Qinghai-Tibet Railway (in Chinese). Scientia Sinica Terrae, 2013, 43: 478-489 
区域性退化状态 ${ }^{[12 \sim 17]}$. 而在工程建设过程中, 又不 可避免地改变了包括微地形(边坡、坡向)、地表覆盖 (植被、积雪、地表水)及浅层土体的热物理性质等在 内的局地因素, 进而改变了复杂的地气边界层的热 交换过程, 影响到下部多年冻土的热状况 ${ }^{[18]}$. 在此背 景下, 青藏铁路建设采用了“冷却路基”思想, 通过采 用包括块石材料、通风管、遮阳篷(板)、热棒、高填 方路堤及添加保温材料等工程措施改变包括辐射、对 流、传热在内的路基传热过程, 主动冷却下部多年冻 土的温度, 以期保证其的长期热稳定性 ${ }^{[19 \sim 21]}$. 其中, 块石路基作为一种廉价且施工方便的路基形式, 在 青藏铁路 $60 \%$ 的高温高含冰量多年冻土区路段得以 采用, 是应用最为广泛的一种冷却路基形式 ${ }^{[2223]}$.

青藏铁路冻土区路基工程于 2003 年全部完工, 目前, 冻土路基已经经历了 7 8 个冻融循环. 期间, 路基下部多年冻土热状况对于路基的修筑及存在如 何响应? 天然状态下青藏高原多年冻土热状况对于 目前正在经历的气候转暖如何响应? 工程扰动及气 候变化双重作用下, 铁路路基长期热状况将如何发 展? 由于, 对于青藏铁路的运营及维护而言, 路基地 温及变形的现场监测以及相应的评价环节至关重要, 它是铁路动态设计与信息化施工建设技术中重要的 一环, 是工程运营方案、路基病害诊断及补强措施应 用的最直接最可靠的依据 ${ }^{[24]}$. 因此, 为研究上述三个 问题, 同时为青藏铁路的运营及维护提供科学依据, 本文基于青藏铁路长期监测系统, 利用现场地温监 测资料开展气候变化及工程活动扰动下铁路路基热 状况研究.

\section{1 青藏铁路长期监测系统}

基于对路基长期稳定性的研究需要, 本研究于 2004 年 9 月开始在青藏铁路沿线建立长期监测系统, 监测内容包括沿线多年冻土地温、路基变形以及西大 滩、北麓河、唐古拉三个站点的气象资料 ${ }^{[25]}$. 在长 550 $\mathrm{km}$ 的多年冻土区路段, 共计布设有 44 个地温及变形 监测断面, 这些断面涵盖了中高山区、高平原、盆地 及河谷地区等地形地貌单元, 海拔在 4423 5080 $\mathrm{m}$ 之 间 ${ }^{[26]}$. 目前, 长期监测系统运行良好, 已获得 2005 2010 年连续性较好的数据监测序列, 其中部分 断面地温监测序列可延伸至 2003 年铁路路基建设初 期.
典型的地温监测断面布设有天然、左路肩、右路 肩、路中心及左坡脚共 5 个位置的测温孔(图 1). 系 统中, 布设有天然孔的断面 37 个, 其中季节冻土区 1 个、融区 6 个、多年冻土区 30 个. 天然孔一般布设 在距离路基坡脚 $20 \mathrm{~m}$ 且无人为活动扰动的地方, 钻 孔深度一般为 $18 \mathrm{~m}$, 部分孔深可达 $40 \mathrm{~m}$, 累积钻孔 深度超过 $600 \mathrm{~m}$. 左、右路肩及路中孔的深度为 $20 \mathrm{~m}$, 坡脚孔深度为 $8 \mathrm{~m}$. 测温孔自表面起沿深度方向每隔 $0.5 \mathrm{~m}$ 布设一个温度探头, 温度探头采用冻土工程国 家重点实验室研制的热敏电阻温度传感器, 其测量 精度可达 $\pm 0.05^{\circ} \mathrm{C}$. 温度数据的采集应用 DT500 型自 动数据采集仪, 采集频率为一天一次. 仪器内所存数 据每两个月下载一次, 下载的同时检查仪器工作状 况以保证监测数据的连续性.

在长 $550 \mathrm{~km}$ 的多年冻土区路段, 除试验路段外, 青藏铁路路基结构形式以块石路基和普通路基为主. 在长期监测系统中, 普通路基断面共计 22 个, 块石 路基断面共计 20 个, 本文的研究对象为块石及普通 路基下部多年冻土的热状况. 青藏公路的长期研究 表明, 对于工程活动的扰动, 多年冻土热状况的响应 是一个短期而快速的过程, 而对气候变化的响应则 是一个长期而缓慢的过程 ${ }^{27}$ 28]. 因此可以通过对比 路基与天然场地浅层地表温度及下部多年冻土上限 的分布来反映多年冻土热状况对于工程扰动的响应, 通过天然场地及路基下部深层冻土地温的动态变化 来反映多年冻土热状况对于气候变化的响应. 由于 处在不同年平均地温分区, 多年冻土对于工程扰动

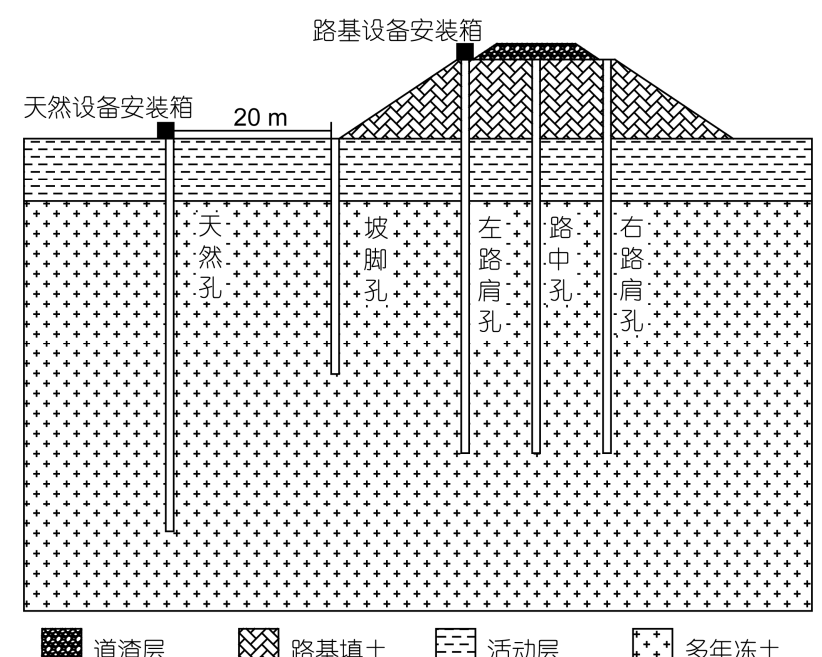

图 1 典型监测断面测温孔及监测设备布设示意图 
及气候变化的响应程度不同 ${ }^{[29]}$, 同时路基结构形式 的差异同样会影响到路基下部多年冻土热状况对于 工程扰动及气候变化的响应过程. 因此, 在下述分析 中将分别对低温冻土区 (年平均地温低于 $-1.0^{\circ} \mathrm{C}$ )与高 温冻土区 $\left(\right.$ 年平均地温高于 $-1.0^{\circ} \mathrm{C}$ ) 的块石路基与普通 路基进行分析.

\section{2 路基热状况对工程扰动的响应}

\section{1 路基浅层地表温度分布}

如图 2(a)地气关系的概念模型所示, 浅层地表温 度受地气热交换过程控制, 该过程因为局地因素的 存在而变得复杂 ${ }^{[30 ~ 33]}$. 局地因素包括地形与朝向、缓 冲层(植被、积雪、有机层覆盖)以及浅层土体的热物 理性质等, 其相互关系如图 2(b)所示. 对于青藏高原 而言, 缓冲层中积雪及有机层覆盖两个因素对于浅 层地温的影响很小. 这是因为青藏高原冬季干燥降 雪较少, 铁路路基很少被积雪覆盖 ${ }^{[34]}$, 且地表基本无 有机层覆盖 ${ }^{[16]}$. 极地多年冻土区与此不同, 尤其是不 连续多年冻土区, 积雪及有机层覆盖对浅层地温及 活动层厚度的影响十分显著 ${ }^{[35 ~ 37]}$. 因此, 路基的修 筑及存在对于浅层地温的热扰动主要由微地形 (路基 填筑及边坡朝向)改变、植被移除以及浅层土体热物 理性质的改变造成. 本文通过对不同年平均地温分 区铁路路基左右路肩及天然孔 $0.5 \mathrm{~m}$ 深度地温进行冷 暖季详细的对比分析来研究工程扰动对浅层地温的 影响, 分析中冷暖季的划分依据为右路肩地温时间 序列曲线.

图 3 分别给出了高平原、老温泉及两道沟断面左

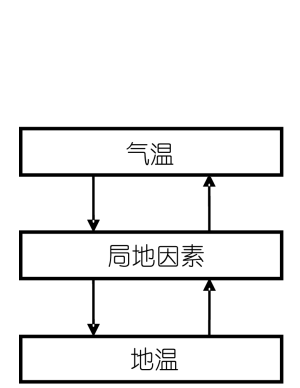

(a)

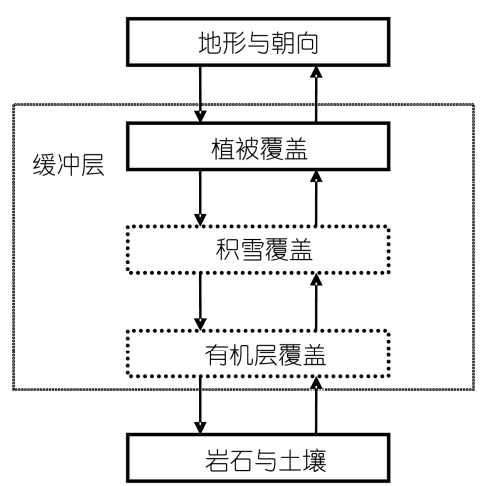

(b)
图 2 地气温度关系概念模型(a)及局地因素组成(b) 修改自文献[31]
右路肩及天然孔 $0.5 \mathrm{~m}$ 深度月平均地温时间序列曲线. 其中高平原断面位于低温冻土区，年平均地温 $-1.5^{\circ} \mathrm{C}$, 路基走向为 $258.8^{\circ}$, 接近东西走向. 老温泉及两道沟 断面位于高温冻土区，年平均地温分别为 -0.4 , $-0.65^{\circ} \mathrm{C}$. 老温泉断面路基走向为 $192.1^{\circ}$, 接近南北走 向; 两道沟断面路基走向为 $230.8^{\circ}$, 介于上述两断面 之间.

暖季时，高平原及两道沟断面左路肩地温高于 右路肩, 右路肩地温又高于天然孔. 其中高平原断面, 左路肩地温高于天然孔在 $1.2 \sim 3.7^{\circ} \mathrm{C}$ 之间, 4 个暖季平 均值接近 $2.0^{\circ} \mathrm{C}$; 右路肩地温高于天然孔在 $0.4 \sim 1.3^{\circ} \mathrm{C}$ 之间, 4 个暖季平均值为 $0.7^{\circ} \mathrm{C}$; 左右路肩地温之间的 差异在 $0.8 \sim 2.3^{\circ} \mathrm{C}$ 之间, 4 个暖季平均值为 $1.2^{\circ} \mathrm{C}$. 两道 沟断面，左路肩地温高于天然孔在 $1.7 \sim 2.2^{\circ} \mathrm{C}$ 之间, 3 个暖季平均值不足 $2.0^{\circ} \mathrm{C}$; 而右路肩地温高于天然孔 在 $0.7 \sim 1.1^{\circ} \mathrm{C}$ 之间, 3 个暖季平均值为 $0.9^{\circ} \mathrm{C}$; 左右路肩 地温之间的差异在 $0.9 \sim 1.4^{\circ} \mathrm{C}$ 之间, 3 个暖季平均值为 $1{ }^{\circ} \mathrm{C}$. 而老温泉断面, 左右路肩及天然孔温度较为接 近, 左路肩与天然孔、右路肩与天然孔及左右路肩之 间的差异为 4 个暖季平均值均不超过 $0.5^{\circ} \mathrm{C}$.

冷季时，高平原及两道沟断面情况相同，左路肩 地温高于天然孔，而天然孔地温高于右路肩. 高平原 断面, 左路肩地温高于天然孔在 $1 \sim 1.3^{\circ} \mathrm{C}$ 之间, 3 个冷 季的平均值为 $1.2^{\circ} \mathrm{C}$; 天然孔高于右路肩在 $1.2 \sim 1.5^{\circ} \mathrm{C}$ 之间, 3 个冷季的平均值为 $1.3^{\circ} \mathrm{C}$; 左右路肩地温之间 的差异在 $2.4 \sim 2.7^{\circ} \mathrm{C}$ 之间, 3 个冷季平均值为 $2.5^{\circ} \mathrm{C}$. 两 道沟断面, 左路肩地温高于天然孔在 $1.1 \sim 1.6^{\circ} \mathrm{C}$ 之间, 3 个冷季的平均值为 $1.4^{\circ} \mathrm{C}$; 天然孔地温高于右路肩 在 $0.3 \sim 0.5^{\circ} \mathrm{C}$ 之间, 3 个冷季的平均值为 $0.4^{\circ} \mathrm{C}$; 左右路 肩之间的差异在 $1.6 \sim 2.0^{\circ} \mathrm{C}$ 之间, 3 个冷季平均值为 $1.8^{\circ} \mathrm{C}$. 而对于老温泉断面, 冷季时, 左路肩地温显著 高于右路肩及天然孔. 其中, 左路肩高于天然孔在 $1.2 \sim 1.3^{\circ} \mathrm{C}$ 之间, 3 个冷季的平均值为 $1.2^{\circ} \mathrm{C}$; 天然孔高 于右路肩在 $0.1 \sim 0.3^{\circ} \mathrm{C}$ 之间, 3 个冷季的平均值为 $0.2^{\circ} \mathrm{C}$; 左右路肩之间的差异在 $0.9 \sim 1.1^{\circ} \mathrm{C}$ 之间, 3 个冷季平均 值为 $1^{\circ} \mathrm{C}$.

通过对老温泉断面的分析可以发现，由植被的 移除、路基与天然场地浅层土体性质差异两个因素所 引起的路基与天然场地浅层地温的差异不显著. 这 是由于青藏高原天然场地植被覆盖度差, 缓冲层效 应不明显，同时天然场地浅层土体多以砂砾、砂砾粉 

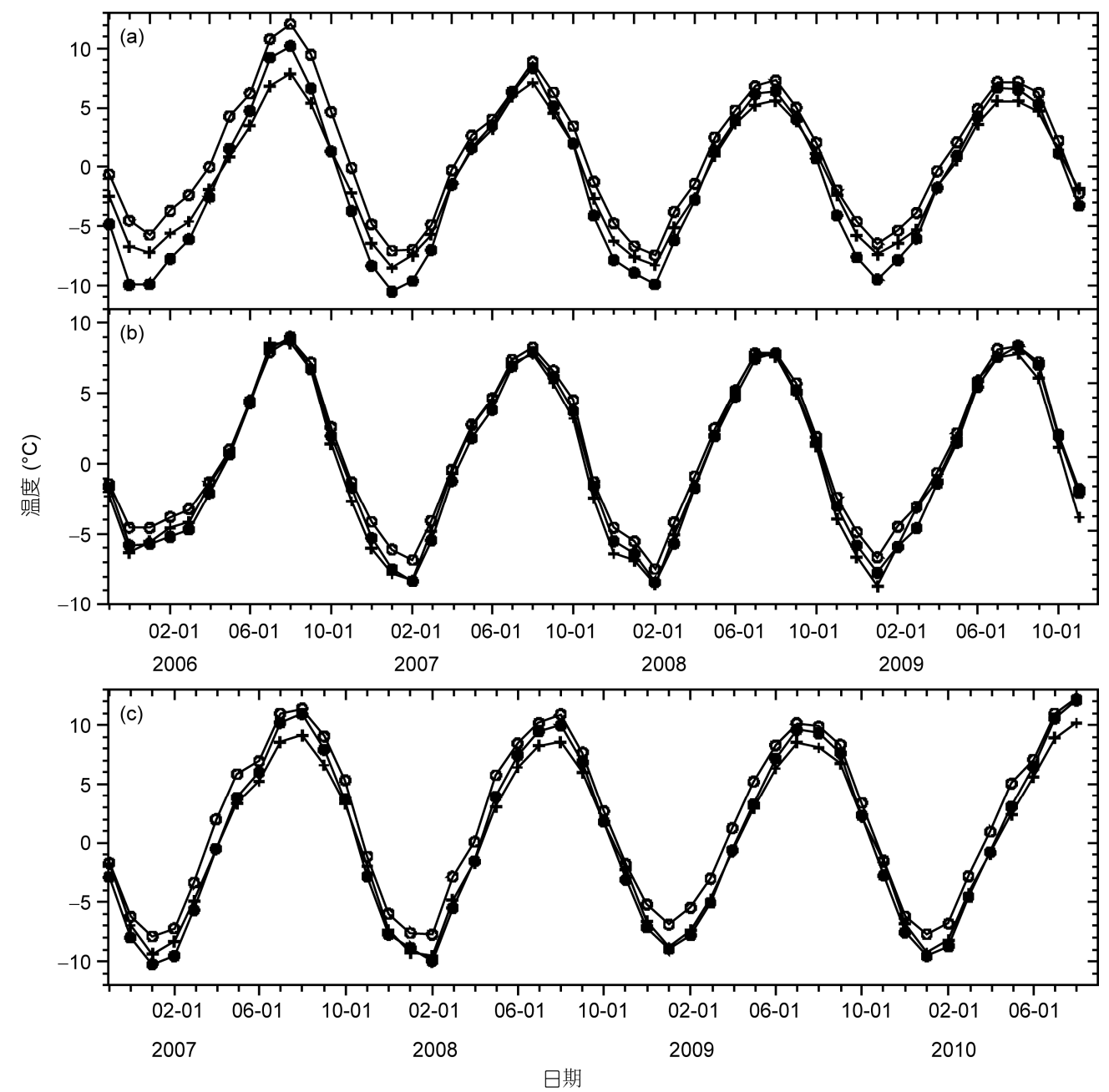

图 3 路基左路肩(空心圆)、右路肩(实心圆)及天然孔(加号)0.5 m 深度地温时间序列曲线

(a) 高平原断面; (b) 老温泉断面; (c) 两道沟断面

土、粉质粘土等为主且较为干燥, 与路基填料状况较 为接近. 而对高平原及两道沟断面的分析表明, 路基 边坡热效应，即路基阴阳坡面接收太阳辐射的差异， 是引起路基与天然场地浅层地温差异及路基浅层地 温分布不均匀的主要因素. 路基边坡热效应可使路 基阴阳坡面浅层地温暖季差异达到 $1.2^{\circ} \mathrm{C}$, 而冷季更 为显著可达 $2.5^{\circ} \mathrm{C}$. 该差异的季节性变化是由太阳高 度角的季节性变化所导致 ${ }^{[38]}$. 青藏铁路自格尔木至 拉萨方向总体走向为东北-西南走向, 即与两道沟 断面走向接近. 因此，阴阳坡面路肩浅层地温的差异 沿路基高度方向的积累势必引起下伏地温的不对称 分布, 不利于铁路路基的稳定, 必须引起足够的重 视.

\section{2 路基内多年冻土上限变化}

对于下部多年冻土热状况而言, 路基的填筑相 当于增加了一层热阻, 热阻保冷与保暖作用的强弱 之比, 将影响到路基内部多年冻土上限及下部冻土 地温的变化 ${ }^{[39]}$. 图 4 给出了路基修筑后, 路基内部地 温场的调整示意图. 表 1 统计了沿线 27 个监测断面 天然上限埋深、路基下冻土上限埋深以及上限的变化, 表中各字母与图 4 中意义相同.

由于路基浅层地温较天然场地浅层地温年较差 大，且路基内部含水量明显小于天然场地活动层内 的含水量, 因此路基内冻土上限埋深 $\left(h^{\prime}\right)$ 普遍较天然 上限埋深 $(h)$ 大 $($ 表 1$)$. 在低温多年冻土区, 块石与普 通路基内 $h^{\prime}$ 与 $h$ 的差值平均值分别为 $0.93,1.78 \mathrm{~m}$; 而 


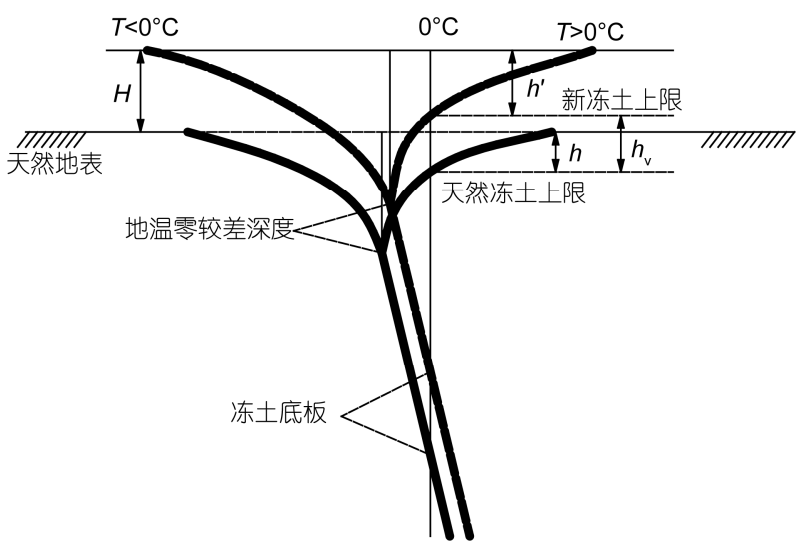

图 4 路基填筑后地温曲线调整示意图

修改自文献[39]. 图中 $H$ 为路基高度, $h$ 为原天然上限, $h^{\prime}$ 为路基修筑 后新的冻土上限, $h_{\mathrm{v}}$ 为路基修筑后多年冻土上限的变化, 其值是 $h^{\prime}$ 与 $H+h$ 的差值
在高温多年冻土区，该差异更加显著，上述两个值分 别增加为 $1.76,3.68 \mathrm{~m}$. 同时不论是块石路基还是普 通路基, 左路肩下冻土上限埋深普遍较右路肩下大. 其中块石路基左右路肩下部冻土上限埋深差异在低、 高温冻土区最大分别可达 $0.9,3 \mathrm{~m}$, 而普通路基左右 路肩上限埋深差异在低、高温冻土区最大分别可达 $2.5,3 \mathrm{~m}$. 路基下部多年冻土上限的不对称分布是路 基边坡热效应的直接反映.

对于路基稳定性而言，工程设计人员更加关注 的是路基下部多年冻土上限的变化情况. 从表 1 中可 以看出，块石与普通路基的 $h_{\mathrm{v}}$ 有着明显不同的表现. 在低温冻土区，块石路基下部多年冻土上限均有显 著的提高, $h_{\mathrm{v}}$ 介于 $1.8 \sim 5.3 \mathrm{~m}$ 之间, 平均值接近 $3 \mathrm{~m}$. 因此，大多数断面下部多年冻土上限已抬升至天然

表 1 青藏铁路沿线监测断面路基下部多年冻土上限变化统计 ${ }^{\text {a) }}$

\begin{tabular}{|c|c|c|c|c|c|c|c|}
\hline \multirow{2}{*}{ 断面位置 } & \multirow{2}{*}{$\begin{array}{c}M A G T \\
\left({ }^{\circ} \mathrm{C}\right) \\
\end{array}$} & \multirow{2}{*}{$H(\mathrm{~m})$} & \multirow{2}{*}{$h(\mathrm{~m})$} & \multicolumn{2}{|c|}{$h^{\prime}(\mathrm{m})$} & \multicolumn{2}{|c|}{$h_{\mathrm{v}}(\mathrm{m})$} \\
\hline & & & & 左路肩 & 右路肩 & 左路肩 & 右路肩 \\
\hline \multicolumn{8}{|c|}{ 低温多年冻土区块石路基 } \\
\hline 高平原 & -1.50 & 3.3 & 2.8 & - & 3.6 & - & 2.5 \\
\hline 五道梁 & -1.48 & 3.2 & 1.8 & 2.0 & $2.5^{*}$ & 3.0 & $2.5^{*}$ \\
\hline 五道梁 & -1.70 & 2.8 & 1.8 & 2.5 & 2.5 & 2.1 & 2.1 \\
\hline 五道梁 & -1.60 & 3 & 1.8 & 2.3 & 2.2 & 2.5 & 2.6 \\
\hline 可可西里 & -2.40 & 4 & 0.9 & 2.0 & 2.5 & 2.9 & 2.4 \\
\hline 红梁河 & -1.50 & 6 & 2.3 & 3.5 & $3.0^{*}$ & $4.8^{*}$ & $5.3^{*}$ \\
\hline 红梁河 & -1.28 & 3 & 2.3 & 3.5 & 3.0 & 1.8 & 2.3 \\
\hline 风火山 & -2.0 & 5.7 & 1.7 & 3.9 & 3.0 & 3.5 & 4.4 \\
\hline \multicolumn{8}{|c|}{ 低温多年冻土区普通路基 } \\
\hline 昆仑山 & -3.17 & 1.0 & 1.9 & 2.0 & 2.0 & 0.9 & 0.9 \\
\hline 斜水河 & -0.75 & 5.5 & 1.1 & 5.0 & 4.0 & 1.6 & 2.6 \\
\hline 清水河 & -0.9 & 4.0 & 3.0 & 6.5 & 4.5 & 0.5 & 2.5 \\
\hline 高平原 & -1.14 & 3.3 & 3.1 & 5.0 & 4.0 & 1.4 & 2.4 \\
\hline 楚玛尔河 & -0.8 & 2.8 & 4.7 & 7.0 & 4.5 & 0.5 & 3.0 \\
\hline 红梁河 & -1.5 & 8 & 2.3 & 4.5 & $4.5^{*}$ & 5.8 & $5.8^{*}$ \\
\hline \multicolumn{8}{|c|}{ 高温多年冻土区块石路基 } \\
\hline 乌丽盆地 & -0.54 & 3.6 & 5.8 & 5.0 & $4.5^{*}$ & 4.4 & $4.9^{*}$ \\
\hline 开心岭 & -0.74 & 3.4 & 2.4 & 4.0 & 4.0 & 1.8 & 1.8 \\
\hline 开心岭 & -0.8 & 3.6 & 2.9 & 5.5 & 5.0 & 1.0 & 1.5 \\
\hline 开心岭 & -0.8 & 3.6 & 3.4 & 5.0 & $5.5^{*}$ & 2.0 & $1.5^{*}$ \\
\hline 布曲河 & -0.46 & 5.7 & 2.7 & 6.5 & 4.5 & 1.9 & 3.9 \\
\hline 托居南 & -0.2 & 7 & 3.5 & 8.0 & 5.0 & 2.5 & 5.5 \\
\hline \multicolumn{8}{|c|}{ 高温多年冻土区普通路基 } \\
\hline 两道沟 & -0.65 & 4 & 0.9 & 6.0 & 5.5 & -1.1 & -0.6 \\
\hline 雅马尔河 & -0.5 & 3.3 & 4.2 & 8.5 & 5.5 & -1.0 & 1.7 \\
\hline 雅马尔河 & -0.24 & 6.2 & 2.4 & 16 & 13 & -8.5 & -4.5 \\
\hline 乌丽盆地 & -0.5 & 3.1 & 3.6 & 7.5 & 6.5 & -0.8 & 0.2 \\
\hline 老温泉 & -0.4 & 3.4 & 2.9 & 6.5 & 5.0 & -0.3 & 1.2 \\
\hline 日阿娜 & -0.27 & 5.0 & 6.8 & 12 & 12 & -0.2 & -0.2 \\
\hline 安多 & -0.12 & 2.4 & 3.5 & 7.0 & 6.0 & -1.1 & -0.1 \\
\hline
\end{tabular}

a) 表中带*的为路中孔上限埋深及变化数据. 数据统计年份: 2003 2010 年 
地表, 即季节性的冻结与融化只发生在路基填土内. 由于路基填土材料为冻胀及融沉非敏感性材料, 因 此这对于路基稳定性而言非常有利. 而在高温冻土 区, 块石路基下部多年冻土上限抬升幅度相对较小, $h_{\mathrm{v}}$ 介于 1 5.5 m 之间, 平均值为 $2.7 \mathrm{~m}$. 块石路基下部 多年冻土上限的显著抬升体现了块石路基冷却降温 的有效性, 避免了由于多年冻土上限下降导致的融 沉变形.

与块石路基相比，普通路基下部多年冻土上限 的变化只取决于路基热阻的 “保温”及 “保冷” 作用的 强弱对比, 而这种强弱对比受到路基高度及所在区 域的年平均气温(地温)控制 ${ }^{[40 \sim 33]}$. 如图 5 所示, 只有 在年平均气温(地温)小于某一临界值时, 路基存在合 理路基高度范围. 当路基高度在此合理范围时, 下部 多年冻土上限将有所抬升, 否则出现下降. 从表 1 中 可以看出, 对于青藏铁路普通路基而言, 该年平均地 温临界值为 $-0.7^{\circ} \mathrm{C}$. 当年平均地温小于 $-0.7^{\circ} \mathrm{C}$ 时, 青 藏铁路路基高度多在合理高度范围内, 因此下部多 年冻土上限均有较为明显的抬升, 有利于路基稳定 性. 除去 P13 断面外, 各断面的 $h_{\mathrm{v}}$ 介于 $0.5 \sim 2.6 \mathrm{~m}$ 之 间, 平均值为 $1.63 \mathrm{~m}$. 而在年平均地温值高于 $-0.6^{\circ} \mathrm{C}$ 的地区, 普通路基左路肩下部多年冻土上限均出现 了明显的下降. 除去 P19 断面外, 各断面左路肩(阳 坡) $h_{\mathrm{v}}$ 介于 $-0.2 \sim-1.1$ 之间, 平均值为 $-0.75 \mathrm{~m}$. 而右路 肩(阴坡)下部冻土上限则有升有降, $h_{\mathrm{v}}$ 介于-0.6 1.7 之间, 平均值为 $0.36 \mathrm{~m}$.

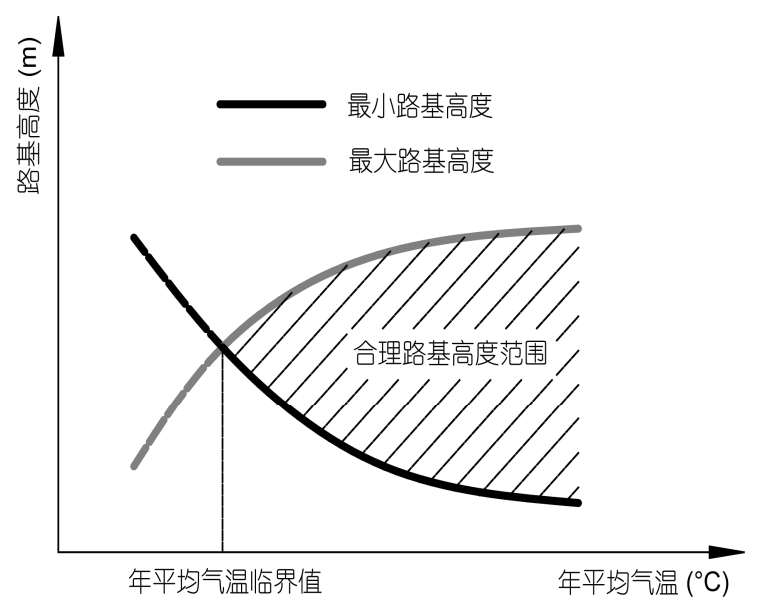

图 5 普通路基合理高度示意图 ${ }^{[39]}$ 横轴箭头表示温度越来越低

\section{3 路基热状况对气候变化的响应}

\section{1 天然状态下多年冻土地温变化}

气象监测资料表明, 自 20 世纪 70 年代起, 青藏 高原开始经历较为显著的升温过程. 1955 1995 年, 整个青藏高原的年平均气温升温速率为 $0.16^{\circ} \mathrm{C}(10$ a $)^{-1}$. 这一升温过程的启动时间早于北半球及全球气 温升温启动时间(19 世纪 70 年代中期), 升温幅度高 于北半球及同纬度地区气温升温幅度 ${ }^{[44]} .20$ 世纪 70 90 年代, 青藏公路沿线的季节冻土、融区及岛状 多年冻土区的地温升高了 $0.3 \sim 0.5^{\circ} \mathrm{C}$, 连续多年冻土 区年平均地温升高了 $0.1 \sim 0.3^{\circ} \mathrm{C}^{[45]} .1996 \sim 2006$ 年, 青 藏公路沿线多年冻土活动层厚度平均增加速率达 7.5 $\mathrm{cm} \mathrm{a}^{-1}$, 而 $6 \mathrm{~m}$ 深度处的冻土地温平均升高 $0.43^{\circ} \mathrm{C}^{[16]}$. 在青藏铁路长期监测系统中, 由于测温孔内温度探 头布设间距较大 $(0.5 \mathrm{~m})$, 因此无法对监测期间天然 场地活动层厚度变化进行精确监测, 这里仅对三个 不同深度的冻土地温动态变化进行分析.

图6 分别给出了 2005 2010年青藏铁路沿线多年 冻土区 14 个断面天然孔多年冻土上限附近及 $6 \mathrm{~m}$ 深 度和 22 个断面 $15 \mathrm{~m}$ 深度地温年平均值的升温情况. 从图 6 可以看出, 在气候变化影响下, 天然状态浅层 及深层多年冻土地温均存在不同程度的升温, 其中 低温冻土区升温幅度较高温冻土区显著. 多年冻土 上限及 $6 \mathrm{~m}$ 深度地温升温幅度最大分别可达 0.31 , $0.36^{\circ} \mathrm{C}$, 即年平均升温速率超过 $0.06{ }^{\circ} \mathrm{C} \mathrm{a}^{-1}$. 两个深 度 14 个断面的平均升温幅度均接近 $0.01^{\circ} \mathrm{C}$, 平均升 温速率为 $0.02^{\circ} \mathrm{C} \mathrm{a}^{-1}$. 这一结果与青藏公路沿线监测 场地在 1995 2004 年的升温速率 $\left(0.022^{\circ} \mathrm{C} \mathrm{a}^{-1}\right)$ 接近 ${ }^{[48]}$. $15 \mathrm{~m}$ 深度地温, 除 2 个高温冻土区断面外, 其余 20 个断面均有一定的升温, 升温幅度最大可达 $0.4^{\circ} \mathrm{C}$. 其中位于昆仑山、风火山及可可西里等中高山区的低 温多年冻土区断面, 年平均地温升温幅度较大, 在 $0.1 \sim 0.4^{\circ} \mathrm{C}$ 之间, 平均升温幅度为 $0.2^{\circ} \mathrm{C}$, 平均升温速 率可达 $0.04{ }^{\circ} \mathrm{C} \mathrm{a}^{-1}$. 而位于楚玛尔河高平原、尺曲谷 地、乌丽盆地、及温泉盆地等高温多年冻土区断面, 年平均地温升温幅度较小, 在 $0 \sim 0.17^{\circ} \mathrm{C}$ 之间, 平均升 温幅度不足 $0.05^{\circ} \mathrm{C}$, 平均升温速率不足 $0.01^{\circ} \mathrm{C} \mathrm{a}^{-1}$. 结合前人对青藏高原冻土升温退化方式的监测及模 拟研究 ${ }^{[14,47]}$, 可以看出目前青藏铁路沿线低温冻土 区多年冻土对于气候变化的响应主要集中体现在多 年冻土升温上, 而多年冻土上限下降速率较小, 多年 


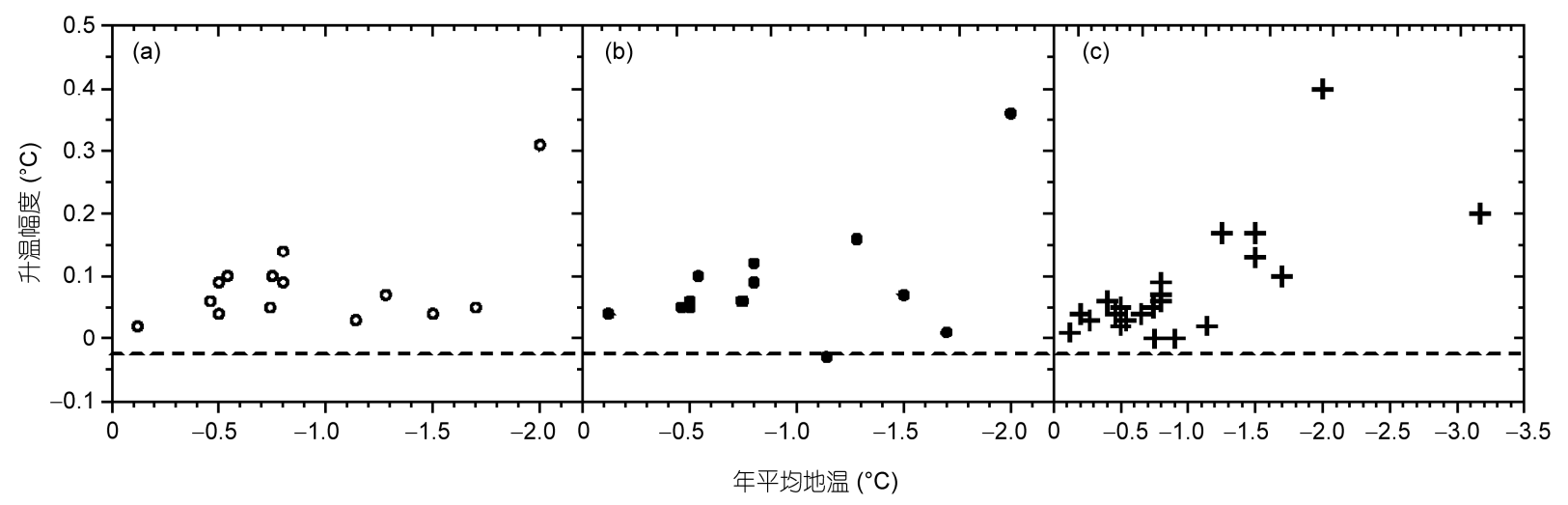

图 6 不同年平均地温断面天然孔不同深度年平均地温升温幅度

(a) 多年冻土上限附近; (b) $6 \mathrm{~m}$ 深度; (c) $15 \mathrm{~m}$ 深度

冻土厚度变化不大; 而在高温冻土区, 多年冻土对于 气候变化的响应主要集中体现在多年冻土上限快速 下降，多年冻土厚度减小，而多年冻土地温升温缓慢. 不同地温分区内多年冻土升温退化所处阶段不同.

\section{2 块石路基下部多年冻土地温变化}

图 7 分别给出了低温、高温多年冻土区块石路基 典型断面左右路肩孔及天然孔 $6 \mathrm{~m}$ 深度地温时间序 列曲线. 数据序列为每天一次, 为增加图的可视性, 数据标记为每 10 或 20 天一次, 后续相同类型图采用 类似处理方法. 从图 7 可以看出, 在低温多年冻土区, 块石路基左右路肩下部 $6 \mathrm{~m}$ 深度冻土地温冷季时存 在明显的“负温积累”, 且均存在较为明显的降温过 程. 这与天然孔在该深度冻土地温冷季无明显的“负 温积累”且存在一定升温趋势形成鲜明对比. 但是, 左右路肩下部该深度地温差异明显, 该差异暖季较 小而冷季明显, 年平均值相差接近 $0.5^{\circ} \mathrm{C}$. 在高温多 年冻土区, 块石路基右路肩下部 $6 \mathrm{~m}$ 深度地温同样在 冷季时存在明显的“负温积累”及降温过程. 而左路 肩下部该深度冷季时无明显的“负温积累”, 且温度 升高, 处于极限热平衡状态. 由此看出, 路基下该深 度冻土地温目前仍主要受到块石路基冷却降温效果 的控制, 同时受到路基边坡热效应的调整作用使得 阴阳坡面路肩下部地温存在较为明显的差异.

图 8 给出了块石路基断面左右路肩孔及天然孔 $15 \mathrm{~m}$ 深度地温年平均值变化情况. 图 8 自左至右, 可 可西里至红梁河 8 个断面位于低温多年冻土区, 开心 岭至安多 6 个断面位于高温多年冻土区(表 1). 在低 温多年冻土区, 块石路基下部该深度地温有升有降,
降温幅度最大的超过 $0.1^{\circ} \mathrm{C}$, 升温幅度最大的接近 $0.2^{\circ} \mathrm{C}$. 通过 4 个布设有天然孔的断面对比可以发现, 块石路基下部该深度冻土地温升温幅度略小于同断 面天然孔升温幅度. 而在高温多年冻土区, 块石路基 下部该深度地温均有一定的升高, 左右路肩孔的平 均升温幅度均大于 $0.15^{\circ} \mathrm{C}$, 且略大于同断面天然孔 的平均升温幅度. 由此看出, 块石路基的冷却降温效 果对下部多年冻土对于气候转暖的响应存在一定的 调整作用: 在低温多年冻土区, 块石路基显著的冷却 降温效果减小了气候转暖对该深度地温的影响; 而 在高温多年冻土区, 块石路基多年冻土上限的抬升 及浅层多年冻土的降温消耗了下部深层冻土地温的 冷量, 加剧了气候转暖对深层多年冻土地温的影响.

\section{3 普通路基下多年冻土地温变化}

图 9 分别给出了低温、高温多年冻土区普通路基 典型断面左右路肩孔及天然孔 $6 \mathrm{~m}$ 深度地温时间序 列曲线. 从图 9 可以看出, 在低温多年冻土区, 普通 路基右路肩下部 $6 \mathrm{~m}$ 深度冻土地温冷季时存在一定 的“负温积累”, 但是无明显升温或降温趋势, 而左路 肩与天然孔地温变化趋势基本相同, 无明显季节性 变化. 在高温冻土区, 左右路肩该深度地温与天然孔 地温相比均存在一定的升温趋势, 且温度均明显高 于天然孔地温. 因此, 对于普通路基来说, 工程施工 的扰动及多年冻土上限的抬升导致路基下部浅层冻 土地温高于天然孔地温, 且由于边坡热效应存在左 右路肩下部冻土地温分布不对称. 从发展趋势上看, 与天然孔地温相同, 普通路基下部该深度冻土地温 将主要受到气候变化的影响. 


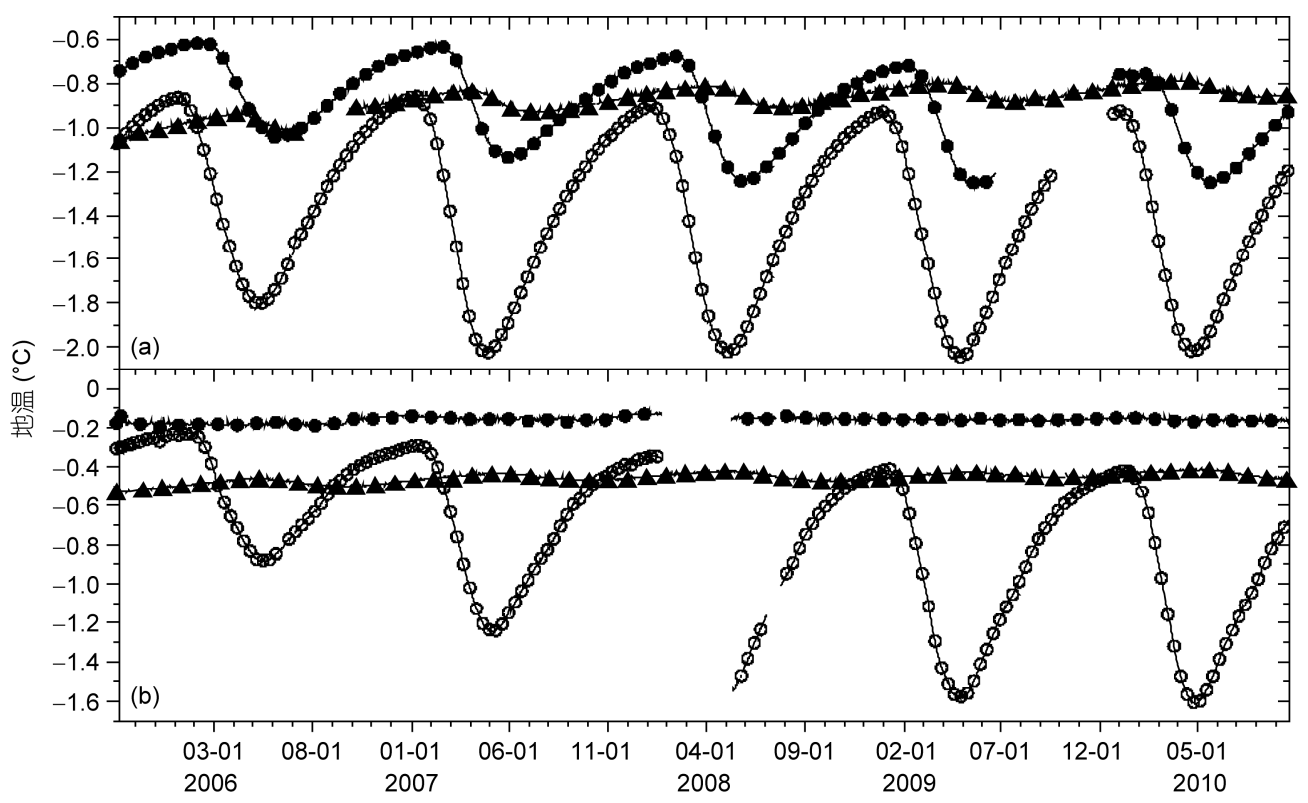

日期

图 7 块石路基右路肩(空心圆)、左路肩(实心圆)及天然孔(三角形) $6 \mathrm{~m}$ 深度地温时间序列曲线

(a) 低温多年冻土区; (b) 高温多年冻土区

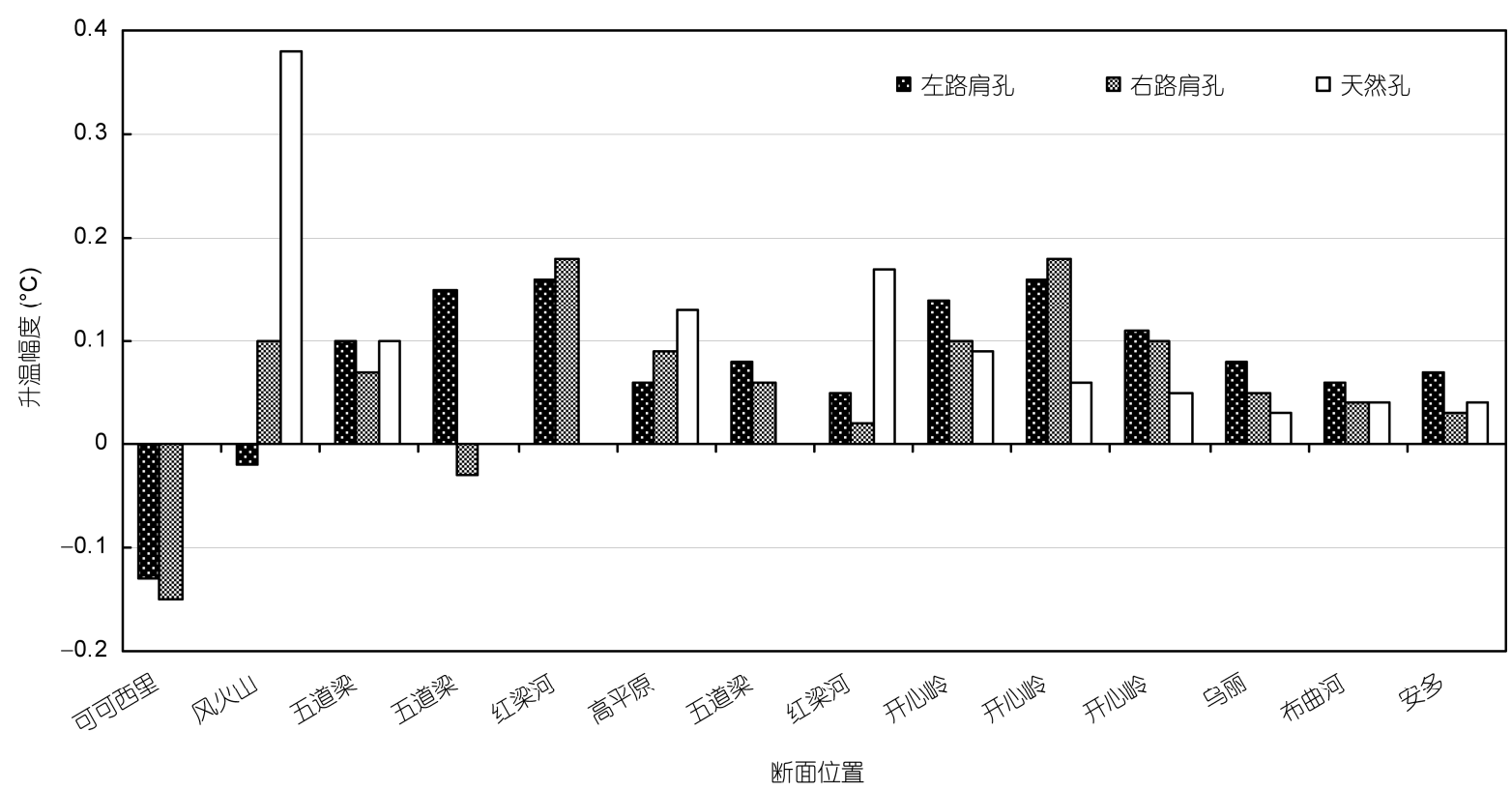

图 8 块石路基断面左右路肩及天然孔 $\mathbf{1 5} \mathbf{~}$ 深度地温变化

图 10 给出了普通路基断面左右路肩孔及天然孔 $15 \mathrm{~m}$ 深度地温年平均值变化情况. 图 10 中, 自左至 右，昆仑山、红梁河、高平原 3 个断面位于低温冻土 区, 清水河至安多 10 个断面位于高温冻土区(表 1). 在低温多年冻土区，普通路基下部该深度地温升温
幅度最大的为 $0.25^{\circ} \mathrm{C}$. 与天然孔对比, 除昆仑山断面 外，其余两个断面路基下部该深度地温升温幅度均 大于同断面天然孔升温幅度. 而在高温冻土区, 普通 路基下部该深度地温均有一定的升高, 且升温幅度 均大于同断面天然孔升温幅度. 由此看出, 不论是在 


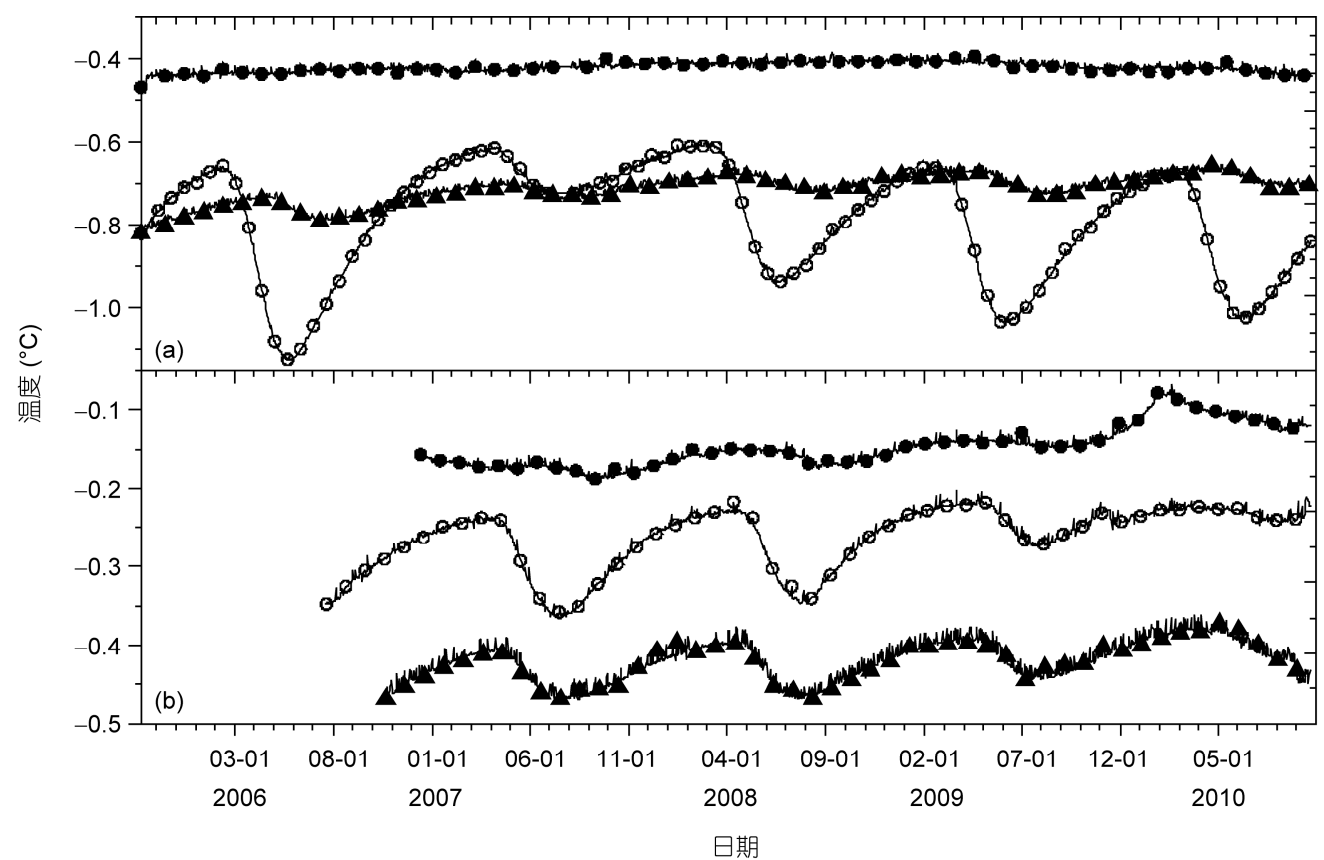

图 9 普通路基右路肩孔(空心圆)、左路肩孔(实心圆)及天然孔(三角形)6 $\mathrm{m}$ 深度地温时间序列曲线 (a) 低温多年冻土区; (b ) 高温多年冻土区

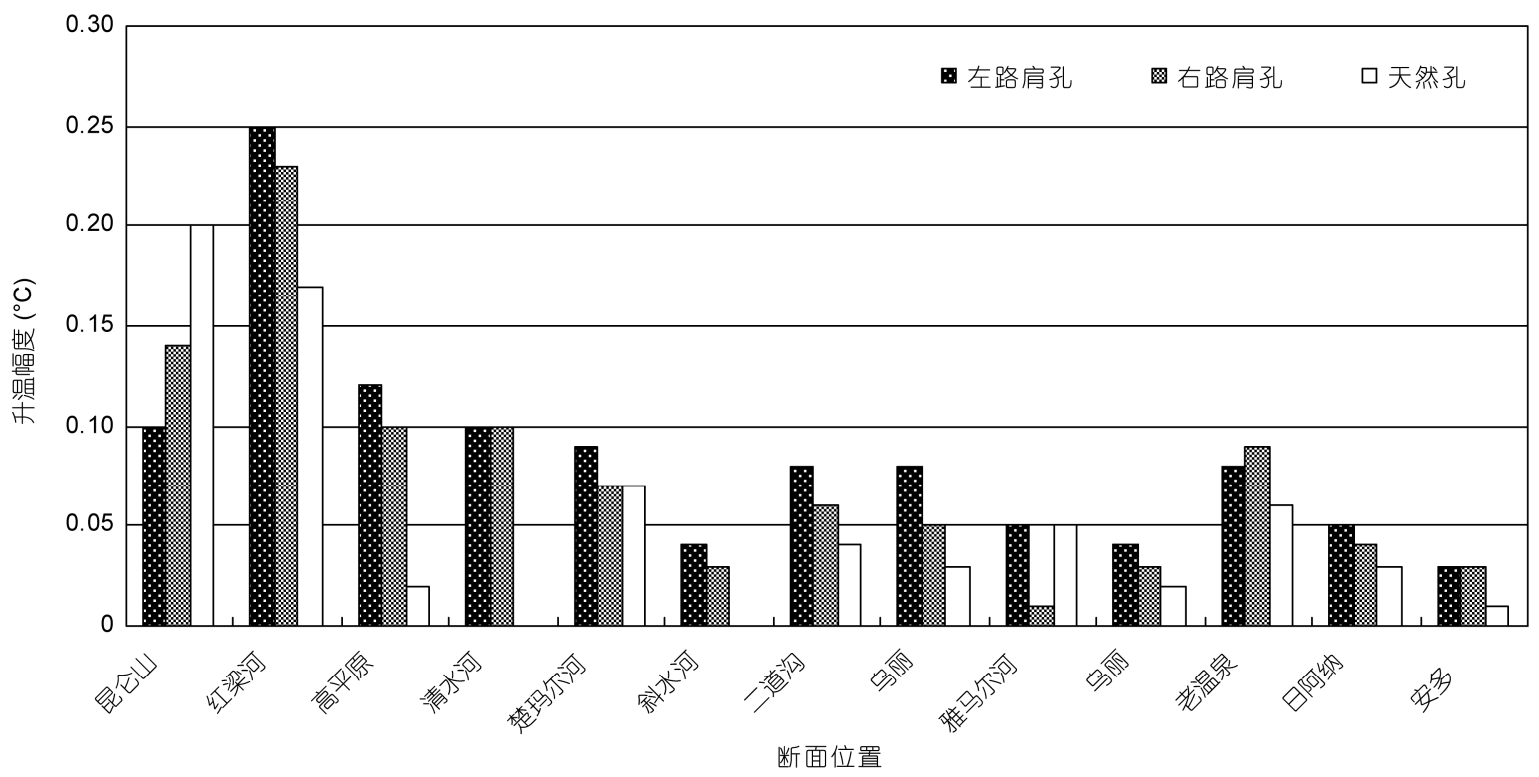

图 10 普通路基断面左右路肩及天然孔 $15 \mathrm{~m}$ 深度地温变化

低温还是高温冻土区, 普通路基下部深层冻土地温 均受到工程扰动及气候变化的双重不利影响. 同时, 路基下部该深度冻土地温在低温多年冻土区升温幅 度均大于高温冻土区, 这与高低温冻土区天然孔冻 土地温变化情况类似.

\section{4 讨论}

基于以上高、低温冻土区块石路基及普通路基对 工程扰动及气候变化的不同响应过程, 参考青藏公 路路基热稳定性定义 ${ }^{[45]}$, 可将目前青藏铁路路基热 
状况分为三类: 稳定型、亚稳定型、不稳定型. 位于 低温多年冻土区的块石路基属于稳定型热状况, 具 体表现为下部多年冻土上限显著抬升、浅层冻土降温 明显而深层冻土地温基本保持稳定. 位于高温冻土 区的块石路基以及位于年平均地温小于 $-0.6 \sim-0.7^{\circ} \mathrm{C}$ 的普通路基属于亚稳定型热状况，具体表现为下部 多年冻土上限较天然上限有一定的抬升, 阴坡路肩 浅层冻土地温较稳定而阳坡路肩浅层冻土地温存在 一定升温趋势, 深层地温存在一定的升温趋势. 年平 均地温高于 $-0.6^{\circ} \mathrm{C}$ 的高温冻土区的普通路基热状况 属于不稳定型热状况, 具体表现为下部多年冻土上 限较天然上限有所降低, 下部冻土地温升温较为显 著. 上述路基热状况的分类与路基整体稳定性监测 结果有较好的对应性 ${ }^{[25]}$ : 在低温多年冻土区, 块石 与普通路基的变形及阴阳坡差异性变形量值较小, 路基整体稳定性较好. 而在高温多年冻土区, 块石与 普通路基均有一定的沉降变形. 尤其是普通路基, 多 年冻土上限下降导致的融沉变形导致路基沉降及阴 阳坡差异性沉降变形量值均较为显著, 路基整体稳 定性较差. 目前, 对于这些路基稳定性较差的路段, 工程人员已经开始通过在路基坡脚处增插热棒或边 坡上铺设块石层等补强措施以保证路基的长期稳定 性.

青藏铁路工程百年大计, 必须考虑路基的长期 热状况 ${ }^{[5]}$. 从目前监测序列看, 不论是块石路基还是 普通路基, 下部多年冻土上限均已稳定, 且块石路基 带来的下部冻土地温冷却降温过程已趋于缓和. 目 前, 由于现场监测时间序列较短, 且现场各种影响因 素较多, 导致得出的结论存在一定的局限性. 因此, 基于本文的研究成果, 下一步将开展多年冻土热状 况对工程扰动及气候变化的响应的理论模型研究, 以便准确预测路基下部多年冻土热状况的发展趋势, 为工程的运营与维护提供科学依据.

致谢感谢三位若名审稿人对本文提出的意见和建议.

\section{5 结论}

通过对青藏铁路沿线天然场地及路基下部浅层 地温、多年冻土上限埋深及变化、不同深度冻土地温 的变化三个方面的对比分析研究了路基下部多年冻 土热状况对于工程扰动及气候变化的响应过程, 得 出以下几点结论.

（1）路基修筑后，阴阳坡面热效应显著，尤其是 在冷季. 该效应可影响到路基内多年冻土上限及下部 冻土地温的分布及变化趋势, 必须引起足够的重视.

（2）块石路基修筑后，下部多年冻土上限均有大 幅的抬升, 平均抬升超过 $2.5 \mathrm{~m}$, 其中阴坡路肩下抬 升幅度普遍较阳坡路基下显著. 普通路基修筑后, 在 年平均地温低于 $-0.6 \sim-0.7^{\circ} \mathrm{C}$ 的地区, 下部多年冻土 上限均有一定的抬升, 平均抬升 $1.63 \mathrm{~m}$. 而在年平均 地温高于 $-0.6^{\circ} \mathrm{C}$ 的冻土区, 阳坡路肩下部多年冻土上 限发生了一定的下降, 平均降幅为 $0.75 \mathrm{~m}$, 阴坡路肩 下部多年冻土上限则无显著变化.

（3）块石路基下部浅层冻土地温目前主要受路 基冷却降温效果控制. 在低温冻土区, 阴阳坡路肩处 该深度地温均存在明显降温过程, 而在高温冻土区 该降温过程只存在于阴坡路肩下. 普通路基下部浅 层冻土地温与天然孔地温变化趋势基本相同, 均存在 一定的升温过程. 路基下部深层冻土地温主要受到气 候变化的影响, 均存在一定的升温过程, 但升温幅度 受到工程扰动的调整作用. 在低温冻土区, 块石路基 的冷却降温效果减小了气候变化对该深度地温的影响. 而在高温冻土区，块石路基及普通路基的修筑，一定 程度上加剧了气候变化对该深度地温的影响.

(4) 依据路基下部多年冻土热状况对工程扰动 及气候变化的响应过程, 可将目前青藏铁路路基热 状况分为稳定型(低温冻土区块石路基)、亚稳定型(低 温冻土区普通路基及高温冻土区块石路基)、不稳定 型(高温冻土区普通路基).

\section{参考文献}

1 Muller S W. Permafrost or permanently frozen ground and related engineering problems. U.S. Engineers Office, Strategic Engineering Study, Special Report No. 62, 1943

2 周幼吾, 郭东信, 邱国庆, 等. 中国冻土. 北京: 科学出版社, 2000

3 Instanes A. Infrastructure: Buildings, support systems, and industrial facilities. In: Instanes A, Anisimov O, Brigham L, et al, eds. Arctic 
Climate Impact Assessment: Scientific Report. Cambridge: Cambridge University Press, 2005. 907-944

4 Bommer C, Phillips M, Arenson L U. Practical recommendations for planning, constructing and maintaining infrastructure in mountain permafrost. Permafrost Periglacial Processes, 2010, 21: 97-104

5 程国栋. 用冷却路基的方法修建青藏铁路. 中国铁道科学, 2003, 24: 1-4

6 马巍, 程国栋, 吴青柏. 多年冻土地区主动冷却地基方法研究. 冰川冻土, 2002, 24: 579-587

7 程国栋. 中国青藏高原多年冻土与加拿大北部多年冻土的一些差别. 冰川冻土, 1980, 2: 39-43

8 Wang B L, Hugh M F. Permafrost on the Tibet Plateau, China. Quat Sci Rev, 1995, 14: 255-274

9 Li X, Cheng G D, Jin H J, et al. Cryospheric change in China. Glob Planet Change, 2008, 62: 210-218

10 Jin $\mathrm{H} \mathrm{J}$, Yu Q H, Wang S L, et al. Changes in permafrost environments along the Qinghai-Tibet engineering corridor induced by anthropogenic activities and climate warming. Cold Regions Sci Technol, 2008, 53: 317-333

11 Wu Q B, Zhang T J, Liu Y Z. Permafrost temperatures and thickness on the Qinghai-Tibet Plateau. Glob Planet Change, 2010, 72: 32-38

12 Cheng G D, Wu T H. Responses of permafrost to climate change and their environmental significance, Qinghai-Tibet Plateau. J Geophys Res, 2007, 112: F02S03

13 金会军, 赵林, 王绍令, 等. 青藏公路沿线冻土的地温特征及退化方式. 中国科学 D 辑: 地球科学, 2006, 36: 1009-1019

14 Wang S L, Jin H J, Li S X, et al. Permafrost degradation on the Qinghai-Tibet Plateau and its environmental impacts. Permafrost Periglacial Process, 2000, 11: 43-53

15 Wu Q B, Liu Y Z. Ground temperature monitoring and its recent change in Qinghai-Tibet Plateau. Cold Regions Sci Technol, 2004, 38: $85-92$

16 Wu Q B, Zhang T J. Recent permafrost warming on the Qinghai-Tibetan Plateau. J Geophys Res, 2008, 113: D13108

17 Wu Q B, Zhang T J. Changes in active layer thickness over the Qinghai-Tibetan Plateau from 1995 to 2007. J Geophys Res, 2010, 115: D09107

18 Anderland O B, Ladanyi B. Frozen Ground Engineering. New Jersey: John Wiley \& Sons. Inc., 2004

19 Ma W, Cheng G D, Wu Q B. Construction on permafrost foundations: Lessons learned from the Qinghai-Tibet Railroad. Cold Regions Sci Technol, 2009, 59: 3-11

20 程国栋, 吴青柏, 马巍. 青藏铁路主动冷却路基的工程效果. 中国科学 $\mathrm{E}$ 辑: 技术科学, 2009, 39: 16-22

21 吴青柏, 程国栋, 马巍, 等. 青藏铁路适应气候变化的筑路工程技术. 气候变化研究进展, 2007, 3: 315-321

22 Ma W, Feng G L, Wu Q B, et al. Analyses of temperature fields under the embankment with crushed-rock structures along the Qinghai-Tibet Railway. Cold Regions Sci Technol, 2008, 53: 259-270

23 吴青柏, 赵世运, 马巍, 等. 青藏铁路块石路基结构的冷却效果监测分析. 岩土工程学报, 2005, 27: 1386-1390

24 Ma W, Cheng G D, Wu Q B, et al. Application on idea of dynamic design in Qinghai-Tibet Railway construction. Cold Regions Sci Technol, 2005, 41: 165-173

25 Ma W, Mu Y H, Wu Q B, et al. Characteristics and mechanisms of embankment deformation along the Qinghai-Tibet Railway in permafrost regions. Cold Regions Sci Technol, 2011, 67: 178-186

26 Wu Q B, Li M Y, Liu Y Z. Thermal Interaction between permafrost and the Qinghai-Tibet Railway. J Cold Regions Engineering, 2010, 24: 112-125

27 吴青柏, 程国栋, 马巍. 多年冻土变化对青藏铁路工程的影响. 中国科学 D 辑：地球科学, 2003, 33(增刊): 115-122

28 吴青柏, 施斌, 刘永智. 青藏公路沿线多年冻土与公路相互作用研究. 中国科学 D 辑: 地球科学, 2002, 32: 514-520

29 吴青柏, 董献付, 刘永智. 青藏公路沿线多年冻土对气候变化和工程影响的响应分析. 冰川冻土, 2005, 27: 50-54

30 Brown R J E. Influence of climatic and terrain factors on ground temperatures at three locations in the permafrost region of Canada. In: 2nd International Conference on Permafrost, Proceedings, North American Contribution, 1973. 27-34

31 Lutin J N, Guymon G L. Soil moisture-vegetation-temperature relationships in central Alaska. J Hydrol, 1974, 23: 233-246

32 Smith M W. Microclimatic influences on ground temperatures and permafrost distribution, Mackenzie Delta, Northwest Territories. Can J Earth Sci, 1975, 12: 1421-1438

33 程国栋. 局地因素对多年冻土分布的影响及其对青藏铁路设计的启示. 中国科学 D 辑: 地球科学, 2003, 33: 602-607

34 Cheng G D, Sun Z Z, Niu F J. Application of the roadbed cooling approach in Qinghai-Tibet Railway engineering. Cold Regions Sci Technol, 2008, 53: 241-258

35 Zhang T. Influence of the seasonal snow cover on the ground thermal regime: An overview. Rev Geophys, 2005, 43: RG4002, doi: 10.1029/2004RG000157

36 Smith S L, Wolfe S A, Risborough D W, et al. Active layer characteristics and summer climate indices, Mackenzie Valley. Northwest 
Territories, Canada. Permafrost Periglacial Process, 2009, 20: 201-220

37 Woo M K, Mollinga M, Smith S L. Climate warming and active layer thaw in the boreal and tundra environments of the Mackenzie Valley. Can J Earth Sci, 2007, 44: 733-743

38 胡泽勇, 钱泽雨, 程国栋, 等. 太阳辐射对青藏铁路路基表面热状况的影响. 冰川冻土, 2002, 24: 121-128

39 程国栋, 张建明, 盛显, 等. 保护冻土的保温原理. 上海师范大学学报(自然科学版), 2003, 32: 1-6

40 程国栋, 童伯良, 罗学波. 路堤填土对冻土上限的影响. 青藏冻土研究论文集. 北京: 科学出版社, 1983. 195-203

41 吴紫汪, 程国栋, 朱林楠, 等. 冻土路基工程. 兰州: 兰州大学出版社, 1988

42 吴紫汪, 朱林楠, 郭信民, 等. 青藏公路多年冻土区路堤的临界高度. 冰川冻土, 1998, 20: 36-40

43 丁靖康, 郝贵生. 年平均气温临界值——设计青藏高原多年冻土区路堤临界高度的一个重要因素. 冰川冻土, 2000, 22: 333-339

44 Liu X D, Chen B D. Climatic warming in the Tibetan Plateau during recent decades. Int J Climatol, 2000, 20: 1729-1742

45 王绍令, 赵秀峰, 郭东信, 等. 青藏高原冻土对气候变化的响应. 冰川冻土, 1996, 18: 157-165

46 吴青柏, 陆子建, 刘永智. 青藏高原多年冻土监测及近期变化. 气候变化研究进展, 2005, 1: 26-28

47 吴吉春, 盛显, 吴青柏, 等. 青藏高原多年冻土退化过程及方式. 中国科学 D 辑: 地球科学, 2009, 39: 1570-1578 